\title{
Macro or micro: The beat goes on
}

\author{
Alden H. Harken, MD, FACS \\ From the Department of Surgery, University of California, San Francisco-East Bay, Oakland, Calif. \\ Disclosures: Author has nothing to disclose with regard to commercial support. \\ Received for publication May 25, 2016; accepted for publication May 26, 2016; available ahead of print June 16, \\ 2016. \\ Address for reprints: Alden H. Harken, MD, FACS, Department of Surgery, University of California, San \\ Francisco-East Bay, 1411 E 31st St (QIC 22134), Oakland, CA 94602 (E-mail: alden.harken @ucsfmedctr.org). \\ J Thorac Cardiovasc Surg 2016;152:932 \\ 0022-5223/\$36.00 \\ Copyright (c) 2016 by The American Association for Thoracic Surgery \\ http://dx.doi.org/10.1016/j.jtcvs.2016.05.042
}

All cardiac dysrhythmias are automatic or reentrant, or a little bit of both. An automatic rhythm derives from a single or small group of irritable cardiomyocytes that fire independently only when they feel like it. Conversely, a reentrant rhythm requires a finely-tuned balance of slow conduction, rapid refractoriness, and anatomic heterogeneity permitting unidirectional block. Thus, an impulse can travel down one electrically unidirectional pathway sufficiently slowly so that when it arrives back at the origin, the origin has had time to repolarize (and be excitable again). This explains why a heart attack can create numerous islands of poorly conductile fibrous tissue that prolong the circumnavigation of an impulse around and through these electrical myocardial pockmarks. It also clarifies why some antiarrhythmic drugs that slow conduction actually can become proarrhythmic by sufficiently retarding the impulse circuit that the origin has had a chance to regain excitability by the time the impulse returns.

For most of us, WPW was our introduction to reentrant rhythms. An atrial impulse whistles through an aberrant atrioventricular conduction pathway (bundle of Kent), courses down the ventricular wall, and then travels back up the septum to reenter the atrium retrograde in a "macro" circuit. In 1973, Jim Cox (the true surgical dysrhythmia pioneer) published a thought experiment, a little like Schrodinger's cat, ${ }^{1}$ with absolutely no data, in which he postulated that a sufficiently heterogeneous scatter of postinfarction myocardial fibrosis might create a sufficiently circuitous reentrant pathway such that an impulse might be delayed long enough to reach the postrepolarized origin, permitting more micro reentry. The reentrant circuit becomes, at least conceptually, a lot smaller. In this issue of the Journal, Knops and colleagues ${ }^{2}$ further shrink the permissible circuitry down to the width of the right atrial wall. The good news is that they have

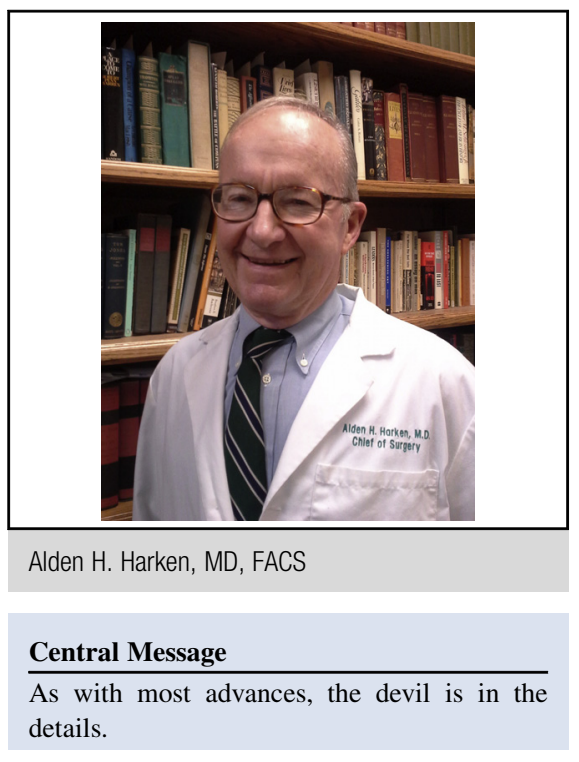

See Article page 929.

accomplished their goal of "gaining insight into the electropathological mechanism of atrial fibrillation." Chronic atrial fibrillation almost certainly reconfigures the juxtaposition of healthy and fibrotic atrial muscle such that the location of the swirling circuitry of atrial fibrillation will be as difficult to pin down as the shifting encampments of al-Qaeda.

But that's okay. The microsubstrate of atrial fibrillation remains therapeutically vulnerable to the surgical channeling accomplished by the Cox-Maze procedure. The authors have persuasively refined our understanding of micro reentrant circuitry from 30,000 to 500 feet, but we still cannot tell whether the shadows roaming the church are nuns or terrorists.

\section{References}

1. Boineau JP, Cox JL. Slow ventricular activation in acute myocardial infarction: a source of re-entrant premature ventricular contractions. Circulation. 1973;48: $702-13$.

2. Knops P, Kik C, Bogers AJJC, de Groot NMS. Simultaneous endo- and epicardial high-resolution mapping of the human right atrial wall. J Thorac Cardiovasc Surg. 2016;152:929-31. 